] O U R A L O F

French and Francophone Philosophy
REV VUE DE LA

philosophie française et de langue française

\title{
Pain as Yardstick: Jean Améry
}

\author{
Ilit Ferber
}

Journal of French and Francophone Philosophy - Revue de la philosophie française et de langue française, Vol XXIV, No 3 (2016) 3-16.

\author{
Vol XXIV, No 3 (2016) \\ ISSN 1936-6280 (print) \\ ISSN 2155-1162 (online) \\ DOI $10.5195 /$ jffp. 2016.784 \\ www.jffp.org
}

\section{(o) EY-NC-ND}

This work is licensed under a Creative Commons Attribution-Noncommercial-No Derivative Works 3.0 United States License.

\section{ULIS D-Sunt}

This journal is operated by the University Library System of the University of Pittsburgh as part of its D-Scribe Digital Publishing Program, and is co-sponsored by the University of Pittsburgh Press 


\title{
Pain as Yardstick
}

\section{Jean Améry}

\author{
Ilit Ferber
}

Tel-Aviv University

One of the best known and most widely accepted premises regarding the experience of pain and suffering is its singular, private nature. Pain's violence isolates us from everything else, embedding us completely within our own suffering so that there is nothing else but pain: no world or objects, no relationship with other people, no past or anticipation of the future. An utter withdrawal. But pain's isolating force is dual: it affects not only those who suffer, but also those who are not in pain. Thus, it is precisely in pain the exemplary state in which we need others with us to offer their help and sympathy - that we find ourselves in solitude; and it is precisely in the state of pain that we leave others to suffer alone. Elaine Scarry famously addresses this problem when she ascribes to pain what she calls its "unsharability". Using geographical metaphors of distance, Scarry compares our relation to the pain of others to the "character of some deep subterranean fact, belonging to an invisible geography [...] the pains occurring in other people's bodies flicker before the mind, then disappear."1

Even more distinctive in Scarry's account is her description of pain as an active form of agency, as if it were attacking us and purposefully acting upon us with its fearful destructive force. ${ }^{2}$ In her view, extreme physical pain triumphs over the suffering subject byvirtue of its unmatched ability to tear up a gaping rift between the sufferer and the rest of humanity. I would like to question this prevailing hypothesis regarding the unsharable, private nature of pain, which has become an almost obligatory reference point in discussions of pain, and suggest a different perspective. Although the nature of violence entails that it is necessarily exercised on an individual's singular, private, and secluded body or soul, its effects extend far beyond this immediate impact. Thus pain's private nature is not only not its central problematic but, moreover, the focus on privacy obscures what I take to be the substratum of the experience of pain and violence: namely, the unique way it alters the world via the new, stark yardstick it imposes on it. It is, however, not only the sufferer's world that is remolded at its very core, but 
our world as well. I will present my argument through a close reading of Jean Améry's account of his experiences of torture and imprisonment by the Nazis between 1943 and 1945 in his At the Mind's Limits. ${ }^{3}$

Améry's writings present us with a strange perplexity. They are directly and explicitly based on his personal experiences, providing us with rare insights into the torture he suffered as well as its effects throughout his later life. And yet the unique character of Améry's writings confronts the reader with an unexpected, even destabilizing experience. Though rooted in autobiography, his writings are conveyed to the reader in an almost distant or cold tone, as if emerging from someone whose cry of pain is so forceful that it breaks all given orders before almost immediately suffocating itself and falling silent. Sebald's description of Améry's singular style is especially astute: "he often expressed only in qualified or very restrained terms. [...] as if every fragment of memory touched a sore point, as if he were compelled to ward off everything immediately and translate it into reflective form to make it at all measurable by any standard. [...] Améry found it in the open method of the essay genre, where he conveyed both the damaged emotions of a man brought to the brink of death and the supremacy of a mind intent on thinking freely even in extremis, however useless doing so might seem."4

These writings, lacking even a shred of self-pity, never adopt a traumatized voice regarding the terrible experiences Améry has endured. It is thus very hard to find the pathos that we tend to look for in memoirs of Holocaust survivors. "If one speaks about torture, one must take care not to exaggerate," he writes, "What was inflicted on me in the unspeakable vault in Breendonk was by far not the worst form of torture." 5 .This is only one example of what can be described as a typical tone of "understatement," to use Sebald's formulation - instead of inviting identification or empathy, Améry positions us before him, the tortured, reporting all the details in the first person, and nevertheless asks that we not be shocked, not feel pity. His descriptions of pain are thus extricated from the private, autobiographical context: "the horrible can make no claim to singularity.". 6 Améry persistently distances his account from the personal, traumatic tone one might expect to encounter and makes a point of challenging the label of the "pathological," which we all too frequently use in the face of those testifying to their horrible experiences, thus providing ourselves with an all-too-easy target for our pity and commiseration. Améry never grants us this opportunity to escape. It is specifically his almost dry tone that keeps us so close to him, precluding any form of withdrawal.

Améry makes a point of telling us something about violence as such, rather than about the specific violence (no matter how terrible) that he endured. He calls us to resist our customary inclination to think of violence only from the victim's perspective - that is, as an aggressive force exerted on an individual's body or spirit-and to give up our instinctive embrace of identification with (or denial of) the victim's suffering. ${ }^{7}$ There is, of course, 
no doubt that Améry experienced, in his own flesh, the terrible isolation inherent in the pain and segregation of torture, but despite this utterly personal experience, despite Améry's body and soul being at stake, he stages the scene, from the first moment, as an encounter that occurs in the public sphere, in the world and not opposite it. The uniqueness of Améry's suspension of intimacy when describing his experience is what allows him to speak about the horror precisely as what is never private or singular, never belonging only to the one whose body is the very body hanging upside down from his wrists, tied to an iron hook in the ceiling. ${ }^{8}$ Violence, rather, exposes something about all of us and is therefore revealed to us all at the same time; what it demolishes is therefore not limited to the confines of a single body or mind. It shatters us all.

\section{"the first blow"}

There is a moment when an act of violence transcends the confines of the body as well as the suffering of the individual and becomes, in an instant, the founding and constitutive principle of human existence as such; from this moment on, one can no longer rise above the space of violence, transcend its affect. Améry describes this moment as that of "the first blow," a phrase that appears as often as ten times in the course of only three pages in Torture. ${ }^{9}$ Although "the first blow" is a physical one, its affect extends beyond the body and the terrible pain it endures. The first blow has a disclosive quality: it "brings home to the prisoner that he is helpless, and thus it already contains in the bud everything that is to come."10Améry's emphasis here is not limited merely to the knowledge of the act of violence or torture that is endured - the blow reveals to the prisoner something about his or her world and the potentialities inherent in its future. The "first blow" reveals that the brutal aggressive act strikes not only the physical body but every possible framework within which it exists - world, time, others - and shatters "the axes of its traditional frames of reference."11 All forms of theoretical knowledge or prediction become "real possibilities, yes, [...] certainties."12. There is no process in which values and principles slowly deteriorate, no advancing "sickness" of a slowly crumbling mind, unconsciously losing everything that kept it together. The force of torture appears, instead, in a brutal instant, a flash, from which there is no return or moreover, any possibility of transcendence. The violent act not only violates the body (or soul), injuring it and piercing through its covering of protective skin; such an act obliterates the very possibility that it might ever be overcome or transcended. From this instant onward, from the moment of the "first blow," violence becomes our only possible yardstick. Now everything can only be measured against it, in and on its own terms. There is no longer causality, logic, or trust - only pain. 
At the beginning of the 1940s, Améry was a member of the Belgian resistance and took part in relatively minor activities such as the distribution of anti-Nazi propaganda to Nazi soldiers. He recounts being familiar with the testimonies and news regarding the possible dangers that would await him were he to be captured, and he recalls that he did not in any way object to being subject to such a bitter fate, thinking that "there could be nothing new" for him. Everything was expected: "Prison, interrogation, blows, torture; in the end, most probably death. Thus it was written and thus it would happen."13 Very soon, however, Améry discovers that these details, which informed his sense of anticipation, were only remotely connected to what, indeed, he would go on to experience. This is clearly not because Améry did not hold all the relevant information or that it was inaccurate, but because the sphere dominated by violence is entirely different from the realm ofinformation, data or even testimony:

That someone is carried away shackled in an auto is 'self-evident' only when you read about it in the newspaper and you rationally tell yourself [...] well of course, and what more? It can and it will happen like that to me someday, too. But the auto is different, and the pressure of the shackles was not felt in advance, and the streets are strange, and although you may previously have walked by the gate of the Gestapo headquarters countless times, it has other perspectives, other ornaments [...] when you cross its threshold as a prisoner. Everything is self-evident, and nothing is self-evident as soon as we are thrust into a reality whose light blinds us and burns us to the bone. ${ }^{14}$

This essential gap is the nucleus of Améry's story. His account does not concern the inherent gap between reality and our conception of it, nor the chasm separating reality and imagination - these types of divergences had been discussed in the history of philosophy for centuries. Nor is it about a veil covering a horrendous abyss, a veil that is suddenly lifted. No. Something else takes place here. It is the act of violence itself that opens up this gap, and it is that painful "first blow" descending on Améry that forcibly tears apart the all-too-delicate fabric of our human existence, of what connects us to other human beings and to the world we share with them. This sudden tear begins with a confined event taking place on a single body in one specific cellar. It is, at first, almost invisible and does not yet threaten the strength and solidity of the entire fabric. Very soon, however, this small tear (and this is how small tears are) widens, expands, and, all too soon, impairs our very stability and wholeness, and hinders us from restoring them. This is a metaphor for what Améry calls the collapse of our trust in the world which abruptly breaks down, is shattered and "will not be regained."15

In his book's final essay, Améry describes a cerain distrust and what he there describes as "unrest" that differentiates him from other people. This 
is, however, not a metaphysical unrest but rather markedly physical and social in nature. It is society that robbed him of his trust in the world and not some metaphysical idea such as Being, Nothingness, God or the Absence thereof. ${ }^{16}$ For Améry, there is an unspoken, almost invisible certainty that exists in the social bond and our commitment to one another, which keeps us together as a collective human entity. Trust, gradually grows out of our life experience, is carefully pieced together from many fragments of memory and feeling: the mother soothing her pained child or the doctor who prescribes the medicine that provides relief: 17 our "trust in the world" is founded on our certainty (closer to belief than to knowledge) that others possess goodness and will respect our boundaries, that our existence matters to them. "In almost all situations in life," Améry explains, "where there is bodily injury there is also the expectation of help; the former is compensated by the latter."18 Even if others hurt us, we have this unconscious yet profound belief that we have all assented to the same social contract, unspoken yet strong, according to which justice ultimately regulates itself. Bernstein interprets this in terms of invisibility and argues that trust is most fully actualized and felt when it is unnoticed, invisible. Consequently, "the ethical foundation of everyday life is a set of attitudes, presuppositions, and practices which we typically fail to emphatically notice until they become absent." 19 It is in its collapse that we come to notice trust, albeit only when it appears in the form of distrust. There is then "a movement from the invisibility of trust to its appearance as unjustified, thus leading to distrust." 20

The invisible certainty of trust, however, buckles and breaks into pieces when the other violates us, when there is nothing we can do to rectify this violation of our borders. Améry's use of the term "border" here has a dual significance: First, the other human being who uses violent force to cause me pain collapses, with his very hands, the delicately balanced border that separates our bodies. Second, with this very strike another border emerges, and this time it is not delicate but fierce, thick. This is the wall that stands between my own vulnerability and suffering on one side, and the belief that the world, or at least someone in it, will come to my rescue on the other. The collapse of one border, therefore, instantly causes another to be erected. But this second wall is strong and threatening and, more importantly, it will not be so easy to tear down. ${ }^{21}$

\section{the impossible}

In Améry's discussion of trust, the invisible is transformed into the impossible. The appearance of distrust is relentlessly entangled with its own impossibility, always marked by its self-negation. Thus in the peculiar dialectic of violence and suffering, the violent event of torture not only opens up an unbridgeable gap at the heart of human existence. What's more, 
it possesses the power to constitute a new mode of existence or consciousness that is paradoxical, or even a-logical, in nature. Broken trust is a hallmark of the paradox: the torturer is no doubt human but at the same time he is an animal; the tortured prisoner is similarly, at once human and animal; reality is abstract yet material at its core; the world is possible and yet, strikingly impossible.

The description of the intellectual's life in the camps in At the Mind's Limits exemplifies this paradoxical structure: the camp represents not only an inversion of the social world or even of trust - it is a violent undermining of everything that had been, until that moment, the logical foundation of existence as such: "You always had to be clean-shaven, but it was strictly forbidden to possess razor or scissors [...] On threat of punishment no button could be missing on the striped inmate suit, but if you lost one at work, which was unavoidable, there was practically no chance to replace it. You had to be strong, but you were systematically weakened." 22 The norms and seemingly unshakeable rules of logic, causality, induction, and social structure - so solid in our daily lives, so certain that we move through them and hardly notice them - were not merely broken but shattered. After the collapse of his initial resistance, the intellectual has recognized that "what may not be, very well could be," and he understood that the utterly impossible, the illogical and paradoxical proved to be starkly possible, asserting itself powerfully in a clear, stable, and consistent manner, just like the logic of the outside world. ${ }^{23}$ It is evidently impossible to live in accord with such a paradoxical perception of reality, which can be described as psychotic, and this not only because it embodies the lack of trust that Améry develops, but since it blocks every possibility of continuity or even mere confidence in the simplest rules of logic. The implications of such a disposition of consciousness lie in the collapse of the ability to predict the future by relying on experience.

Up until the "first blow" the tortured individual lived in a world that was believed to be founded on basic social solidarity. This has changed after the "first blow," but not because the tortured man discovered that evil exists or now knows something he didn't before. The change has to do with his acknowledgment that there is a possibility, even if slight, that things are not as he believed them to be, not as they should be, and finally: not as they were. The psychotic element here has to do with the fact that even if one knows he is protected, his predator is behind bars or dead and no one will ever turn him into an animal again; Even then, there is still the slightest possibility that this would happen. Although the war is over and the horror has ended - it has, in fact, never ceased and is always recurring: "Whoever was tortured, stays tortured," Améry famously writes, "It was over for a while. It still is not over [...] In such an instance there is no 'repression.' Does one repress an unsightly birthmark?"24 
Primo Levi gives an interesting account of this persistent feeling of doubt that is accompanied by the suffocating recurrence of the impossible, when he describes a recurring dream he had after the war was over. In the dream, he is peacefully sitting at the dinner table with his family or friends, and yet, although no threat is in sight, he has a clear feeling of distress. Levi continues: "And, in fact, as the dream continues, bit by bit or all of a sudden - each time it's different - everything falls apart around me, the setting, the walls, the people. The anguish becomes more intense and pronounced. Everything is now in chaos. [...] at once I know what it means, I know that I've always known it: I am once again in the camp, and nothing outside the camp was true. The rest - family, flowering nature, home - was a brief respite, a trick of the senses." 25 What figures so powerful in Levi's description is his binding of the completely unexpected (the falling apart of intimacy, family and security) with that which he always knew was true, lurking there ("I know what it means, I know that I've always known it"). The possibility that the most concrete, solid feeling of life and world is, in fact, a dream, would seem to be utterly impossible. Yet, after the first blow, it becomes a possibility and will always remain so.

Pain and violence are obviously a part of our world and of the flesh of our humanity - and yet it is impossible for such experiences to take part in our world. This paradoxical essence of violence is why we cannot treat the violent act as a merely "non-human" act standing outside the borders of what we take to be human. It is here, right here; yet when it emerges, violence appears before us as something whose presence we cannot possibly bear. Violence is human and in-human at the same time - a part of our very world, yet impossibly part of it. Violence appears, therefore, together with the impossibility of its appearance. It is baldly present, yet its presence is unbearable. This is a stark demonstration that the certainty usually attached to the experience of violence and pain is only one side of the story. Being a victim of a violent act, at the same time (and perhaps to a greater extent), testifies to a strong doubt, to extreme skepticism: it is me standing here, in my own, familiar world, $1+1=2$, and yet, perhaps none of this is true. Skepticism as a philosophical stance makes a point of not being merely immersed in the everyday, unconsciously floating with its currents, butstops short at the unquestionable, to doubt, to put oneself in a position that is farthest as can be from the realm of the evident. The victim of torture, on the other hand, does not choose his doubt; he is violently forced into the impossibility of skepticism, together with the ever-present possibility that this is all a dream.

Améry's account of the twisted, distorted sense of temporality characteristic of resentment epitomizes the case in which suffering affects not only the body of its individual victim but transforms the structure of time itself. He draws a distinction between what Améry refers to as the natural and moral modalities of time, the first belonging to forgiveness, the 
latter to resentment. Those who forgive do so "lazily and cheaply," he writes, subjugating themselves to the sentiment that time heals all wounds, and turn themselves to the future which Améry describes as the "genuine human dimension." 26 Those who are filled with resentment, experience temporality entirely differently: time, ceasing to be biological and social, has moved into the moral sphere (Resentment: 71). Améry uses a very critical, even scornful tone when speaking of those who believe in the natural power of the passing of time, modeled on the physiological processes of woundhealing. For him, human beings are distinguished precisely by their ability to struggle against the passing of time, resentment being the tenacious yet hopeless revolt against time's passage and its natural, corrective effects. ${ }^{27}$

According to Ben Shai's interpretation of Améry's disordered temporality, which he takes to be the leitmotif of At the Mind's Limits as a whole, the twisted sense of time belongs to a higher order that has, in Améry's view, "something deeply instructive, and in that sense privileging, about it. This has to do with the claim that only when subjected to such inhuman condition do we come face to face with a fundamental truth about the human condition itself." 28 I find this claim to be a crucial element in Améry's insistent attempts to release his account of suffering from the subjective or psychological spheres. In this context, his resolute struggle with what he calls natural time, in favor of moral time, is not an attempt to overcome suffering, but rather "to preserve its negative effects while elevating it to the place of public concern, insight and knowledge." 29 Extreme suffering has the quality of opening up and disclosing that which those who forgive and those who believe in the healing powers of time's natural course fail to see. The suffering of torture puts the victim in a limbo where no experience is reliable, no trust possible; yet at the same time, it possesses the singular power to uncover the illogical, twisted infrastructure of the core of human existence.

Maurice Blanchot's provocative remarks on suffering and temporality are illuminating in this context. In the first part of The Infinite Conversation, he describes the experience of suffering as that of a deliverance to a starkly different temporal realm: "to time as other, as absence and neutrality; precisely to a time that can no longer redeem us, that constitutes no recourse. A time without event, without project, without possibility; not that pure immobile instant, the spark of the mystics, but an unstable perpetuity in which we are arrested and incapable of permanence, a time neither abiding nor granting the simplicity of a dwelling place." 30 I find Blanchot's argument here to be in close kinship with Améry's: both emphasize that the unique, twisted temporality of suffering is very far from being its mere negation. It is not an "outside" of time or its simple arrest by way of an obsessive recurrence of the past (with this claim, both distance themselves from the framework of the traumatic). Suffering's temporality allows no relationship to a future or to any form of projection, since these are 
conditioned by a distance that is impossible for the tortured, who is "crucified" to his suffering in Améry's account. For Blanchot, the experience of suffering is the paragon of the co-existence of necessity and impossibility; suffering "makes time a present without future and yet impossible as present [...] affliction makes us lose time and makes us lose the world [...] It is life become alien and death become inaccessible. It is the horror of being where being is without end." 31

\section{birthmark}

It is for this reason that the "first blow" is not merely physical and is not only felt on the individual body of the tortured; it is a "blow" to the rules of logic and to trust, to the possibility of deduction and the natural confidence in our past experiences. After the first blow, there is and always will be the possibility that everything will fall apart. No induction or logic will be of help here since we have learned, on our own flesh, that nothing is certain and that anything, no matter how illogical, can indeed occur. For Améry, therefore, every day is like the first and the last: "Every day anew I lose my trust in the world." 32 This is his scar, his birthmark. ${ }^{33}$

The force of Améry's writing lies, as I insist here, in its assertion that the pathological, skeptic and distrustful forms of existence do not belong to him alone. The scar is not embossed only on his body; it becomes the plight of all of us, not only those who were hung upside-down from their wrists in a cellar somewhere, but also of those who were not, and almost certainly will never be. Therein lies the heart of my argument: Améry leads us into his own psychosis and there is no way out, not for him and not for us. He shows us that this is not a pathology or neurosis, but rather, an irrefutable truth, a reality: "The others are the madmen, and I am left standing around helplessly among them, a fully sane person who joined a tour through a psychiatric clinic and suddenly lost sight of the doctors and orderlies." 34 We are now with him, sharing his unavoidable doubt that the world might not always respond to our expectations (of logic, causality, society). We understand that such a possibility exists; whether it will ever be actualized is irrelevant. Insofar as we are part of the same world, we also and inevitably take part in the same possibility that it may collapse.

The uniqueness of Améry's writings among survivor memoirs lies in his ability to express the twofold, and tragic, nature of violence. The autobiographical experience, private traumatic memory and the survivor's terrible testimony are put forth together with (but not at the expense of) Améry's ability to describe the experience of pain and violence as what essentially transcends the private, subjective realm. This is one of the reasons for my decision not to incorporate any detailed descriptions of pain and violence here (although Améry did write such descriptions, and they are sometimes graphic). I suggest that we read Améry as follows: the singular, 
tortured, suffering victim does not appear as the sole protagonist occupying the stage, offering his lacered body as an object of our pity (victim vis-à-vis witnesses). The description of the specificity of torture, therefore, does not preclude our grasping the universal implications of pain and violence. On the contrary - and here lies Améry's greatness - the personal conditions the universal, allows it to appear and to do so with such starkness. It is not, of course, my intention here to undermine or underestimate the suffering and cruelty of the single blow to a specific body; each act of this nature deeply breaks the body and soul of its victim. However - and this cannot be stated too emphatically - the echoes of the blow always resound far, very far, from a particular originating body or event. Despite the specificity of its affliction (it always has to be directed towards someone or something), violence hits, with all its force, everything that is human, breaking what makes up our world into pieces.

This image of pain, in which the suffering of a single individual necessarily and immediately touches all of humanity, in which a single strike in a dark cellar forces an irreparable tear into humanity's fabric, might sound like an exemplary, not to say ideal, portrayal of humanity. This description, however, fails to grasp the reality in which this fabric has long been worn out and tattered from acts committed in cellars, from countless blows and humiliations, and it is now slit and shredded throughout. This is why, according to Améry, "Whoever has succumbed to torture can no longer feel at home in the world" (Torture, 40). It is here that his crystal-clear writing is transformed: from prose expressed in a poised voice to a series of sad, cracked wails from someone who feels that he is utterly and deeply incurable.

This metamorphosis happens not because he himself cannot obliterate the horror, and not because he bears terrible, almost physical memories of his own pain that will never, he now grasps, go away. The reason lies elsewhere, perhaps in an unexpected place: it emerges when the tortured takes leave of the dark cellar and re-enters the human world that, surprisingly to him, still goes about its daily business:

My neighbor greets me in a friendly fashion, Bonjour, Monsieur; I doff my hat, Bonjour, Madame. But Madame and Monsieur are separated by interstellar distances; for yesterday a Madame looked away when they led off a Monsieur, and through the barred windows of the departing car a Monsieur viewed a Madame as if she were a stone angel from a bright and stern heaven [...] Bonjour, Madame, Bonjour, Monsieur, they greet each other. But she cannot and will not relieve her sick neighbor of his mortal illness at the cost of suffering to death from it herself. And so they remain strangers to one another [...] Thus I am alone, as I was when they tortured me. ${ }^{35}$ 
The transformation occurs outside the cellar, in the world that, Améry now realizes, can truly and utterly erase its own history. When the torture is over and its suffering has ended, when the wounds have healed and the tortured body exits the cellar and ventures back into the world - then he sees that everything has changed, and yet nothing has changed.

The sturdy dividing wall, which rose up in place of the vulnerable border of human trust that had collapsed with the first blow, now marks a thin, almost invisible, but impenetrable line. It separates those whose bodies were subject to violence and unbearable pain, and those who were not touched by its hand. ${ }^{36}$ This sounds close to Scarry's famous claim that pain achieves its triumph over us by means of what she calls its "unsharability," the essential characteristic of what cannot be communicated, shared, and known by others. Although some of Améry's formulations are similar to those of Scarry, their accounts differs in important ways. Améry makes clear that although there might be an essential separation between the tortured and those who were spared, we are all part of the same world, a world that is now wholly altered, for all of us, from the moment of the first blow. My argument here is that unlike Scarry, for Améry the rift exists within the world itself and therefore belongs to us all. We might never have to cross over to the side of suffering: however, we can never ignore the unbridgeable gap that now exists, and will never cease to exist, in our shared world. Améry has, in other words, made us part of his incurable, tattooed suffering, precisely because we exist on its other side - for how can we, too, "repress an unsightly birthmark?"37

What, then, does Améry leave us with? Should we be satisfied with his testimony about the unbridgeable gap between himself and us? Between the pained, suffering ones and those who can only regard such pain from afar? Should we remain aloof from such a dispiriting conclusion? Or should we, perhaps, aspire to the impossible, that is, to the complete and utter identification with the suffering of others, or to the desperate attempt to cure and repair? Clearly, no: such attempts are doomed to be sentimental, moralistic, or simply impossible (since even the deepest, most committed identification would never turn us into those who were hung, from their own wrists, upside down from a cellar's ceiling). Perhaps we have to settle for a diminished possibility, the only one we still have, and acknowledge that the only response that remains at our disposal is to feel this gap, to acknowledge that we cannot, principally, take part in the suffering of others, nor can we mend it. Perhaps this "thin" acknowledgement is what will be our own "portion" of pain. Pain stemming from the fact that none of us and not only Améry, can ever really feel at home in our world. 
1 Elaine Scarry, The Body in Pain: The Making and Unmaking of the World (Oxford University Press, 1988): 3,4. A similar argument was also made by Susan Sontag in her Regarding the Pain of Others (Farrar, Straus and Giroux, 2003).

2 Scarry, The Body in Pain, 3-4, 13.

3 Jean Améry, At the Mind's Limits: Contemplations by a Survivor on Auschwitz and its Realities, trans. Sidney Rosenfeld and Stella P. Rosenfeld (Indiana University Press, 1980).

${ }^{4}$ W. G. Sebald, “Against the Irreversible: On Jean Améry," in On the Natural History of Destruction, trans. Anthea Bell (Random House, 2003), 151.

${ }^{5}$ Améry, "Torture," in At the Mind's Limits, 22 (hereafter: Torture).

${ }^{6}$ Torture, 22.

7 See also Ariel Handel who argues that taking the perspective of the victim is the only possible anchor for a discussion of violence (Handel, "Violence," Mafte'akh, Vol. 3 [2011]: 53-80 [Hebrew]).

8 Torture, 32.

9 Torture, 26-29, 40.

10 Torture, 27.

11 Torture, 19.

12 Torture, 27.

13 Torture, 25.

14 Torture, 25-26.

15 Torture, 28, 40.

16 Jean Améry, “On the Necessity and Impossibility of Being a Jew," in At the Mind's Limits: 100 (hereafter: Jew).

17 Torture, 28-29.

18 Torture, 29.

19 J. M. Bernstein, “Trust: On the Real But Almost Always Unnoticed, Ever-Changing Foundation of Ethical Life,” Metaphilosophy, Vol. 42, No. 4 (2011): 395. Roy Ben-Shai makes a similar claim in his "To Reverse the Irreversible: On Time Disorder in the Work of Jean Améry," in Ed. James Watson, Metacide: In Pursuit of Excellence (Rodopi, 2010), 78.

20 Bernstein, “Trust," 403.

21 Blanchot's understanding of "community" is important in this regard. As Andrew Benjamin points out, instead of emphasizing the relation of sameness as a constitutive factor of community, Blanchot uses the figure of distance and the in-between which "allows for the introduction of a sense of alterity. Rather than merely being the other to the same, alterity in this context is defined in terms of founding 'irreciprocity'” (Benjamin, “Another Naming, a Living Animal: Blanchot's Community,” SubStance, vol. 37, no. 3 [2008]: 212.) 
${ }^{22}$ Améry, “At the Mind's Limits,” in At the Mind's Limits, 10 (hereafter: Limits)

23 Limits, 11, 10. When he discusses the convoluted nature of resentment, Améry resorts again to the category of an illogical logic: "In pondering this question, it did not escape me that resentment is not only an unnatural but also a logically inconsistent condition. It nails every one of us onto the cross of his ruined past. Absurdly, it demands that the irreversible be turned around, that the event be undone" (Resentment, 68).

${ }^{24}$ Torture, 34, 36.

25 Primo Levi, “Ad ora incerta,” in Opere, Vol. 2 (Turin: Einaudi, 1988): 245-55, quoted in Giorgio Agamben, Remnants of Auschwitz: The Witness and the Archive, trans. Daniel Heller-Roazen (Zone Books, 1999), 101.

26 Jean Améry, “Resentment," in At the Mind's Limits, 68, 72 (hereafter: Resentment).

27 Resentment: 72. Améry's discussion of resentment has an explicit historical flavor to it. Presenting his own resentment as an absurd yet at the same time humane demand, Améry links it to a moral-historical task: "Perhaps it is only concern for my own purification, but I hope that my resentment-which is my personal protest against the antimoral natural process of healing that time brings about, and by which I make the genuinely humane and absurd demand that time be turned back-will also perform a historical function. [...] This demand is no less absurd and no less moral than the individual demand that irreversible processes be reversible" (Resentment, 77). The logical impossibility of the victim joining his nemesis in the no-man'sland of twisted temporality, within the "annulment of time," is precisely what renders Améry's wish moral (Resentment, 72). See also David Heyd's interesting discussion of the historical dimension of Améry's account of disordered temporality, as well as his analysis of the differences between Améry's and Nietzsche's understanding of resentment: Heyd, “Die Etik des Resentiments oder Die Taktlosigkeit des Jean Améry," in Eds.: Ulrich Bielefeld, Yfaat Weiss, Jean Améry: “... als Gelegenheitsgast, ohne jedes Engagement” (Wilhelm Fink, 2014), 13-30.

${ }^{28}$ Ben Shai, “To Reverse the Irreversible," 78.

29 Ben Shai, “To Reverse the Irreversible,” 77.

30 Maurice Blanchot, The Infinite Conversation, trans. Susan Hanson (University of Minnesota Press, 1993), 44.

31 Blanchot, The Infinite Conversation, 120. Blanchot's arguments about the phenomenology of the disaster are interesting in this context: see Blanchot, The Writing of the Disaster, trans. Ann Smock (University of Nebraska Press, 1986).

32 Jew, 94.

33 Torture, 36.

${ }^{34}$ Jew, 96.

35 Jew, 95-96.

${ }^{36}$ Sebald briefly alludes in this context to Emil Cioran's beautiful account of death as dividing line (Sebald, “Against the Irreversible," 162). Let me quote Cioran's full passage: “And it is death, the most intimate dimension of all the living, which separates humanity into two orders so irreducible, so removed from each other, that there is more distance between them than between a vulture and a mole, a star and a starfish. The abyss of two incommunicable worlds opens between the man who has the sentiment of death and the man who does not; yet both 
die; but one is unaware of his death, the other knows; one dies only for a moment, the other unceasingly. . . . Their common condition locates them precisely at each other's antipodes, at the two extremities and within one and the same definition; irreconcilable, they suffer the same fate. . . . One lives as if he were eternal; the other thinks continually of his eternity and denies it in each thought" (E. M. Cioran, A Short History of Decay, trans. Richard Howard (Arcade Publishing, 2012), 11.

${ }^{37}$ Torture, 36. 